Volume 9, No.3, May - June 2020

International Journal of Advanced Trends in Computer Science and Engineering

Available Online at http://www.warse.org/IJATCSE/static/pdf/file/ijatcse211932020.pdf

https://doi.org/10.30534/ijatcse/2020/211932020

\title{
Internet Communications in the Context of Restrictions on Population Mobility
}

\author{
Elena Borisovna Shtukareva ${ }^{1}$, Svetlana Sergeeva ${ }^{2}$, Yulia Zolotukhina ${ }^{3}$, Aleksandr Orlyuk ${ }^{3}$, \\ Igor A. Kopylov ${ }^{4}$ \\ ${ }^{1}$ Russian State Social University, Moscow, Russia \\ ${ }^{2}$ Moscow State Institute of International Relations (University) of the Ministry of Foreign Affairs Russian \\ Federation, Moscow, Russia \\ ${ }^{3}$ Moscow Metropolitan Governance University, Moscow, Russia \\ ${ }^{4}$ Russian Academy of National Economy and Public Administration under the President of the Russian \\ Federation, Moscow, Russia
}

\begin{abstract}
The Internet is a means for developing a specific type of communications - Internet communications. The Internet is the most dynamically progressive means of communication, since the latest means of communication have made it possible to combine disparate communication systems in a global network, in which cross-border information-sharing is carried out across the globe. Today, in the context of restrictions on population mobility, the problem of using Internet communications has become more acute.

Based on the results of an expert survey, the authors have identified the most significant possibilities of using Internet communications in the context of restrictions on population mobility, which include the use of Internet communications in distance education of students, as well as in the remote completing of job duties by employees.
\end{abstract}

Key words : Internet, Internet communications, population mobility restrictions, distance education, remote work.

\section{INTRODUCTION}

The coronavirus epidemic (COVID-19), which originated in China and spread rapidly around the world, has come as a terrible surprise for all its inhabitants. On March 11, the World Health Organization (WHO) declared a global pandemic as the coronavirus rapidly spreads across the world. According to Tedros Adhanom Ghebreyesus, the Head of the WHO, the world has never before seen such a pandemic. However, countries can still change its course if the patients are identified and isolated in time. He encouraged countries to develop a strategy to prevent the spread of infection [1].

To counter the threat, prevent the spread of coronavirus and minimize its impact, the authorities of many states had to resort to the introduction of anti-epidemic measures and numerous restrictions. Many countries introduced movement restrictions, sealed borders and imposed quarantine or a state of emergency. Given the emergency, most of these restrictions on population mobility are justified to protect human life and health.

Due to the existing situation, the use of Internet communications as a specific type of communication in the modern global Internet is becoming especially relevant as a way of reducing possible problems in people's life [2, 3].

Internet communication provides unlimited access to the global information flow, allowing one to take an active part in the communication process, become a direct participant and act as a communicant, who creates and distributes information $[4,5]$.

Scientists refer variously to the communication environment on the Internet: virtual space; cyberspace; sociocultural, information and communication environment $[6,7]$; computer-mediated communication $[8,9]$, electronic communication, virtual communication, etc. $[4,10]$.

Scientists pay attention to the cross-border nature of communication between users on the Internet (the uncertainty in the number of anonymous users and the extent of information distribution), as well as the shift in the hierarchical order of information distribution (from the vertical order with one dominant subject to the equitable one) and bilateralism [11].

Researchers note the special role of virtuality in the information and communication society and highlight its following characteristics: it is interactive (interactivity is characterized by the transformation of mass media into mass communication); hypertextual (hypertextuality is represented by the Internet); global; creative (virtual reality provides a person with maximum opportunities for constructive activity); anonymous and mosaic (can be characterized by the formation of chaotic structures) [12]. S.E. Caplan adds the following characteristics to this list: it is decentralized; operational; multimedia; open; capacious; user-controlled; infrastructurally independent; generally available; intended 
to meet the information and communication needs of individuals and social groups. He also includes in characteristics its global dimensions, social and communicative nature of the network and the fact that it enters the electronic communication system due to the use of a computer database and telecommunications technologies [13].

The communicative opportunities offered by the Internet (such as social networking, participating in projects, searching for required information, corresponding, listening to music, watching videos, sharing media files, playing games, etc.) develop more and more possibilities for self-expression and self-realization. Besides, virtuality provides the expansion of cognitive practices and the growth of visual thinking [14]. Thus, the resources of computer communications provide opportunities for dialogue between subjects, who are in remote locations, which is especially important in the context of restrictions on population mobility.

Nowadays, in the context of restrictions on population mobility, social networks have become the main means of communication, support, youth development, as well as the exchange of information, metadata and so forth. The most commonly used social networks and communities are Facebook.com, Instagram.com, video hosting Youtube.com, mobile application Viber and others [15].

According to researchers, the use of Internet communications by young people is more advisable as a tool for education and self-education [16]. The development of information and communication technologies offers them new opportunities by expanding the sphere of communication with Internet users. Thus, they are included in informal education, which is currently taking place on social networks, specialized information sites, blogs and portals, where one can find the required information, communicate with specialists and exchange information [17].

Internet communications can be carried out in different ways. If one speaks about the receiver of a message, correspondence can be divided into personal and collective correspondence, as for response time - the types are synchronous (online communication mode) and asynchronous communication (offline communication mode) [18]. Among computer systems for interpersonal communication, the following types are distinguished:

1) synchronous personal correspondence. It includes chat, in which the message, typed by one of the participants, is automatically displayed on the monitor of another participant, and they answer in the same way, continuing the dialogue;

2) asynchronous personal correspondence. It includes e-mails. The user types a message and sends it to the addressee, who, after receiving it, sends a response if necessary;

3) synchronous collective correspondence. This refers to chat rooms, when the participants of group discussion take turns exchanging messages;

4) asynchronous collective correspondence. Its main form is online conferences (forums). The message sent to the conference becomes available to all its participants. Each participant can answer it, supporting the discussion, and also raise new questions [19].

At present, webinars have become popular. It is the format of various online events, during which communication between participants is maintained via the Internet using a computer or a special web application [20, 21].

The purpose of the article is to identify the most significant possibilities of using Internet communications in the context of restrictions on population mobility based on an expert survey.

The research hypothesis is that the most significant process in the context of restrictions on population mobility may become the use of Internet communications in distance education of students, as well as in the remote completing of job duties by employees.

According to the results of the study, it can be concluded that the objective was achieved.

\section{METHODS}

In the research process, the following methods were applied:

- analysis of scientific literature on the characteristics of Internet communications;

- an expert survey to identify the most significant possibilities of using Internet communications in the context of restrictions on population mobility. The participants in the expert online survey were 40 experts: members of local governments.

\section{RESULTS}

The most significant possibilities of using Internet communications in the context of restrictions on population mobility were identified based on the expert survey (Table 1).

Table 1: Possibilities of using Internet communications in the context of restrictions on population mobility

\begin{tabular}{|c|c|c|c|}
\hline No. & $\begin{array}{l}\text { Internet communications in the context } \\
\text { of restrictions on population mobility }\end{array}$ & $\% *$ & $\begin{array}{c}\text { Ran } \\
\mathrm{k}\end{array}$ \\
\hline 1 & $\begin{array}{l}\text { Distance education of university } \\
\text { students }\end{array}$ & $\begin{array}{l}95 \\
\% \\
\end{array}$ & 1 \\
\hline 2 & Distance education of school students & $\begin{array}{l}90 \\
\%\end{array}$ & 2 \\
\hline 3 & Remote work (telework) & $\begin{array}{l}80 \\
\%\end{array}$ & 3 \\
\hline 4 & $\begin{array}{l}\text { Internet communications as a means } \\
\text { of public administration }\end{array}$ & $\begin{array}{l}65 \\
\% \\
\end{array}$ & $4-5$ \\
\hline 5 & $\begin{array}{l}\text { Internet communications as a means of } \\
\text { state control }\end{array}$ & $\begin{array}{l}65 \\
\% \\
\end{array}$ & $4-5$ \\
\hline
\end{tabular}

Note: compiled based on the expert survey; ${ }^{*}$ - percentage of expert references 
The results of the survey revealed that, according to the experts, the most significant process in the context of restrictions on population mobility may become the use of Internet communications in distance education of students, as well as in the remote completing of job duties by employees.

\section{DISCUSSION}

Distance education students. As the vast majority of the experts (95\% of the respondents) noted, an important factor in student support in the context of restrictions on population mobility is to continue their proper education.

One of the means of information and communication technologies, which can help students to get access to the learning materials at any time and any place in the context of restrictions on population mobility, is the technology of distance (online) education, the use of which makes the learning process accessible and comfortable and stimulates education and self-education during the period of restriction.

According to one of the respondents, "in non-standard emergencies, it is necessary to act quickly and effectively, choosing easy, convenient, understandable tools".

The implementation of distance education is possible using full-fledged systems (Moodle, Google Classroom, Blackboard $-85 \%$ of the respondents), as well as the familiar instant messaging software applications (Viber, Telegram, etc. $75 \%$ of the respondents) or social networks (Facebook and others $-70 \%$ of the respondents).

Moreover, multifunctional tools for organizing distance education exist as well - the free online services such as Google Classroom (70\% of the respondents), Blackboard (60\% of the respondents) and others. However, some of them are paid.

The easiest and minimal option to support the educational process in the context of restrictions on population mobility is the use of instant messaging software applications and social networks (70\% of the respondents). There the target groups are created (for example, according to the fields of study), in which students are added for distribution of the links to educational materials and tasks for independent work. Student groups, already existing in the Dean's offices, can be used. Students themselves can also help to organize electronic groups. It is desirable to avoid excessive division into groups and ensure that no students are added into several groups and that everyone stays focused.

To share video content, it is possible to broadcast live video on YouTube and save video material after for reuse. Besides, one can broadcast live video via Facebook, as well as Instagram, which students especially like. The date and time of the beginning of the broadcast and links to the preserved video materials could be placed in above-mentioned students groups. If there is a need to record the screen to save the video, then such easy-to-use services as Loom and oCam can help (65\% of the respondents).

Systems such as Learning Apps and Google Forms (60\% of respondents) are useful for online tests or quizzes. The latter has the option to add an Excel spreadsheet and receive all the results in real-time.

The following is a brief description of the web technologies, online platforms and software useful for organizing the educational process in the context of restrictions on population mobility. The table is based on the expert survey (Table 2).

Table 2: Services for organizing the educational process in the context of restrictions on population mobility

\begin{tabular}{|c|c|c|c|c|}
\hline No. & Service & Opportunities & $\begin{array}{c}\text { Ran } \\
\mathrm{k}\end{array}$ \\
\hline 1 & Google Classroom & $\begin{array}{l}\text { A web service, that ties Google Docs, Google Drive and Gmail together; helps to create and } \\
\text { distribute assignment, give grades, comment on issues and organize the effective and efficient } \\
\text { communication with the students in real-time or in the mode of distance education. Access to } \\
\text { this service is possible after registration and getting a regular Google account. With the help } \\
\text { of Google Classroom, a user can create a classroom or join an existing one. The number of } \\
\text { classes that can be created or joined is not limited. }\end{array}$ & $1-2$ \\
\hline 2 & Moodle & $\begin{array}{c}\text { Moodle is a free and open-source learning management system. It allows using a wide range } \\
\text { of tools for educational interaction between teachers, students and school administration. In } \\
\text { particular, it allows presenting educational material in various formats (texts, presentations, } \\
\text { videos, web sites, or a combination of web sites with possible intermediate tests); testing } \\
\text { students using closed-ended questions (question with options from which to choose a } \\
\text { response) and open-ended questions; completing assignments with the option to forward the } \\
\text { related files. Also, the system has a wide range of tools for monitoring of the educational } \\
\text { process. }\end{array}$ & $1-2$ \\
\hline 3 & $\begin{array}{c}\text { Cloud storage, } \\
\text { Google Drive } \\
\text { (Office365, Google) }\end{array}$ & $\begin{array}{c}\text { Provides the opportunities to create a multifunctional user environment. The advantages of } \\
\text { using it are: all tools are free; no installation is required; it is available for all operating } \\
\text { systems and client programs; all Google Drive tools are accessible from one account; it allows } \\
\text { working collectively synchronously or asynchronously, editing, viewing or commenting on }\end{array}$ & 3 \\
\hline
\end{tabular}




\begin{tabular}{|c|c|c|c|}
\hline & & $\begin{array}{l}\text { documents together with students, controlling their work without distracting them; checking } \\
\text { students' work interactively; creating a shared database; posting students works with limited } \\
\text { access rights (only for a particular number of users); quickly collecting and analyzing } \\
\text { information, creating tests and quizzes, designing charts and diagrams. The materials are free } \\
\text { and accessible } 24 \text { hours a day. }\end{array}$ & \\
\hline 4 & $\begin{array}{c}\text { Google Forms } \\
\text { (creating tests, } \\
\text { surveys and quizzes) }\end{array}$ & $\begin{array}{l}\text { A tool that allows quickly developing a survey or a quiz: creating a form, preparing an } \\
\text { assignment, choosing the type of answer. Also, Google Forms can facilitate the work with } \\
\text { parents and simplify the communication with them. Thus, at the beginning of the school year, } \\
\text { the class teacher can ask parents to fill in the form to get the answers to standard questions. }\end{array}$ & 4 \\
\hline 5 & $\begin{array}{l}\text { Online Board Padlet } \\
\text { (http://padlet.com/) }\end{array}$ & $\begin{array}{l}\text { It can be used as a platform for collective work for brainstorming, generalization and } \\
\text { systematization of knowledge and reflection; for posting educational materials and practical } \\
\text { tasks; for organizing online collaboration in doing homework; for posting project ideas and } \\
\text { their online discussions; for organizing collective work of students. }\end{array}$ & $5-6$ \\
\hline 6 & Kahoot & $\begin{array}{l}\text { This platform is designed for creating quizzes, tests and didactic games. The service can be } \\
\text { used to test students' knowledge. Students can complete tasks using any device that has access } \\
\text { to the Internet - a smartphone, tablet, etc. Photos and videos can be inserted into tasks. The } \\
\text { teacher can give points for correct and fast completion of the task. The registration is } \\
\text { conducted with the help of a Google or Microsoft account, so there is no need to create new } \\
\text { logins or passwords. Tests can be duplicated or edited, which is very time-saving. }\end{array}$ & $5-6$ \\
\hline 7 & Edmodo & $\begin{array}{l}\text { It is a truncated version of a social network similar to Facebook, which allows teachers and } \\
\text { pupils to communicate with each other during the learning process at school. }\end{array}$ & 7 \\
\hline 8 & LearningApps.org & $\begin{array}{l}\text { An online service that allows creating interactive exercises. It is helpful in the elaborating } \\
\text { various tasks for different subjects both for children and high school students. These tasks can } \\
\text { be used during the lessons and in the free time. Besides, Learningapps.org offers distance } \\
\text { education opportunities for teachers, since it allows one to create several classes in one } \\
\text { account, add information about students in their profiles, set an entry password and post tasks } \\
\text { for students. }\end{array}$ & 8 \\
\hline
\end{tabular}

Note: compiled based on the expert survey

Remote work (telework). According to one of the experts, "scientific and technological development encourages the rapid development of various forms of employment. In particular, this concerns an atypical form of employment, which is becoming increasingly important in the context of restrictions on population mobility". Typical employment refers to traditional employment under an open-ended labour contract, when the labour activity is carried out at the enterprise under the immediate supervision of the director during normal working hours.

Scholars have not yet developed a unified approach to understanding atypical employment. Yet, according to one of the experts, "it is the labour activity of workers of a certain classification group, provided for or not prohibited in the current legislation. However, due to the specific organization of working hours, workplaces and working conditions, it does not correspond to standard rules and requires special organizational and economic security". Nowadays, according to the experts, in the context of restrictions on population mobility, new atypical forms of employment appeared in the labour market, among which remote work is worth mentioning.

The use and distribution of information technology in the modern world are increasing. As a result of these processes, many workers, even before the imposition of restrictions on population mobility, worked remotely (distantly) outside the offices of the employer, using modern technology, computer networks and telecommunication devices in their work. In the European documents, the term "remote workers" is applied to such workers, and the work itself is called "remote work" and is indicated in authentic texts as "telework" or "telecommuting". On July 16, 2002, the European Union signed the Framework Agreement on Telework [22].

There is no unambiguous definition of remote work in the scientific community. Researchers clarify, that a "remote" worker is the person who works at home, using a computer and communicating with the colleagues or customers via phone, fax or e-mail [23].

K.L. Fonner and M.E. Rollof identify four main types of remote work [24]:

home-based work, carried out by full-time and part-time workers, using telecommunication technologies;

work, carried out by freelancers or self-employed workers, using some forms of telecommunication technology;

mobile telework, carried out by mobile teleworkers, who spend at least 10 hours a week outside the main workplace and use some form of telecommunication technology;

full-time day extenders, who sometimes continue work at 
home after working hours or on weekends, using some form of telecommunication technology.

According to S. Hornung and J. Glaser, teleworking is a new form of employment, which manifests itself in home-based low-skilled work, home-based skilled work and mobile telework. The authors indicate its main advantages over traditional employment: saving time, as well as money, that could have been spent on transport to work and flexible working hours [25].

The experts, participating in the survey, pointed to the great diversity of telework types. Considering such aspects as the use of telecommunications technology and the type of workplace, they distinguished the following types:

1. Partially remote work, which is divided into work at home and in office. Work that is performed mainly by credible highly qualified personnel. Most of the time is spent on work at home (accountant, designer, etc.) - in the context of restrictions on population mobility, it is possible to switch to telework.

2. Freelance remote work. Home-based work that is carried out by freelancers under the labour contract with the employer (journalist, writer, translator). Internet communications are needed to present the results of the work.

3. Mobile telework. Home-based work that involves the use of new technologies. Employees contact customers using computer equipment and telecommunications and provide them with the necessary services (trade representatives, hotline operators).

4. Work in special workplaces. The employer creates special offices provided with telecommunications. Teamwork is expected (programmer, designer, marketer, etc.).

The experts emphasized (75\% of the respondents) that in the atmosphere of the dynamic development of global and local corporate computer networks, especially in the context of restrictions on population mobility, the need to concentrate the labour activity in one place disappears. At the same time, virtual enterprises appear as an antithesis to the traditional organizational forms: groups of people who can cooperate synchronously or asynchronously using network technologies, regardless of their physical location [26]. In this sense, remote work appears as a by-product of new industrial relations in the information society.

\section{CONCLUSION}

The following conclusions can be drawn from the study.

Internet communications in the context of restrictions on population mobility are a tool for self-development. They allow one to find other people and interact with those who are significant for them and master the "new" virtual space, its options and features. They are a process of education, creative self-expression and communication that can be remote and anonymous. They build social capital as an instrument of "social monitoring" and maintaining social contacts. In the process of using Internet resources, certain skills of working with media products are formed that allow making navigation in the information and communication space easier.

Thus, in the context of restrictions on population mobility, when it is forbidden to attend educational institutions, and teachers must perform other organizational and pedagogical work, according to the vast majority of respondents, the use of distance education is the optimal solution.

Almost equally significant is the use of Internet communications in the remote completing of job duties by employees in the context of restrictions on population mobility. The peculiarity of remote work concerns three components: the nature of the work, which involves primarily intellectual activity (rather than manual labour); the use of such modern means and types of telecommunications as fax, telephone, computer with Internet access, e-mail, web interfaces, etc., which provide the opportunity to communicate with colleagues, leadership, as well as directly with clients of the employer (customers of work and services), in on-line mode.

The results of the study confirmed the hypothesis that the most significant process in the context of restrictions on population mobility may become the use of Internet communications in distance education of students, as well as in the remote completing of job duties by employees.

\section{REFERENCES}

1. VOZ obyavila o pandemii koronavirusa [WHO declared the coronavirus outbreak a global pandemic]. Retrieved from:

https://www.rbc.ru/society/11/03/2020/5e6912ac9a7947 26b69d8ea7

2. T.I. Golubeva, N.V. Linder, K.K. Zoidov, V.V. Pterov, D.A. Maximov, U.U. Abdulkadirov. Criterion analysis of cloud-based tools in database basics training. Revista Inclusiones, vol. 7, no. especial, pp. 520-534, 2020.

3. S. Pivneva, N. Vitkovskaya, O.N. Makarov, D.K. Benikovna. Integration of network capabilities of blended learning. Revista Inclusiones, vol. 7, no. especial, pp. 192-206, 2020.

4. O.N. Morozova. Osobennosti Internet-kommunikatsii: opredelenie i svoistva [Characteristics of Internet communication: definition and properties]. Vestnik of Pushkin Leningrad State University, vol. 1, no. 5, pp. 150-158, 2010.

5. A.V. Lobuteva, L.A. Lobuteva, O.V. Zakharova, S.A. Krivosheev, A.D. Yermolaeva. Specifics of problem-based learning in the pharmaceutical education process. Journal of Advanced Pharmacy Education \& Research, vol. 9, no. 2, pp. 131-136, 2019.

6. S.V. Bondarenko. Sotsialnaya struktura virtualnykh setevykh soobshchestv [The social structure of virtual communities]. Rostov: Izdatelstvo Rostovskogo Universiteta Publ. Company, 2008. 
7. S. Pivneva, D. Denisova, N. Vitkovskaya, R. Zakieva, E. Muraya, G. Ushakova. Advanced Information Technology: Automated and Individual Learning Systems. International Journal of Advanced Trends in Computer Science and Engineering, vol. 8, no. 6, pp. 3481-3487, 2019.

https://doi.org/10.30534/ijatcse/2019/125862019

8. M.A. Egorova. Otkliki i otsenochnye kommentarii pri kompyuterno-oposredovannoi kommunikatsii [Feedback and evaluative comments in computer-mediated communication]. Vestnik of Voronezh State University, no. 1, pp. 15-20, 2014.

9. T.V. Ponomarenko, M.A. Nevskaya, O.A. Marinina. Innovative learning methods in technical universities: the possibility of forming interdisciplinary competencies. Espacios, vol. 40, no. 41, p. 6, 2019.

10. G.A. Vorobev. Virtualnaya mezhkulturnaya sreda [Virtual intercultural environment]. Journal Vysshee obrazovanie v Rossii, no. 7, pp. 98-101, 2007.

11. T.W. Brignall, T. van Valey. The impact of Internet communications on social interaction. Sociological Spectrum, pp. 335-348, 2005. https://doi.org/10.1080/02732170590925882

12. J. Bargh, K.Y.A. McKenna. The Internet and social life. Annual Review of Psychology, vol. 55, pp. 573-590, 2004.

13. S.E. Caplan. Preference for online social interaction: A theory of problematic Internet use and psychosocial well-being. Communication Research, vol. 30, pp. 625-648, 2003.

14. J. Cummings, B. Butler, R. Kraut. The quality of online social relationships. Communications of the ACM, vol. 45, pp. 103-108, 2002. https://doi.org/10.1145/514236.514242

15. T.D. Baruah. Effectiveness of Social Media as a tool of communication and its potential for technology-enabled connections: A micro-level study. International Journal of Scientific and Research Publications, vol. 2, no. 5, pp. 123-144, 2012.

16. J.S. Lee, H. Cho, G. Gay, B. Davidson, A. Ingraffea. Technology Acceptance and Social Networking in Distance Learning. Educational Technology \& Society, vol. 6, no. 2, pp. 50-61, 2003.

17. S. Misra, L. Cheng, J. Genevie, M. Yuan. The iPhone effect: The quality of in-person social interactions in the presence of mobile device. Environment \& Behavior, pp. 1-24, 2014

18. M. Tanis, T. Postmes. Social cues and impression formation in computer-mediated communications. Journal of Communication, vol. 52, no. 4, pp. 676-693, 2003.

19. G. Blank, D. Groselj. Dimensions of Internet use: amount, variety, and types. Information Communication \& Society, vol. 17, no. 4, pp. 417-435, 2014.

https://doi.org/10.1080/1369118X.2014.889189
20. M.M. Grant, J. Cheon. The value of using synchronous conferencing for instruction and students. Journal of Interactive Online Learning, vol. 6, no. 3, pp. 211-226, 2007.

21. R.S. Kuanysheva, A.Z. Asainova, M.I. Ragulina, M.P. Lapchik. Developing Ict Competences In Bachelor Of Engineering And Technology In A Multilingual Environment. International Journal of Education and Practice, vol. 7, no. 3, pp. 123-135, 2019.

22. Framework agreement on telework. Brussels, 2002. Retrieved from: https://www.etuc.org/en/framework-agreement-telework

23. D.G. Allen, R.W. Renn, R.W. Griffeth. The Impact of Telecommuting Design on Social Systems, Self-Regulation, and Role Boundaries. Research in Personnel and Human Resources Management, vol. 22, pp. 125-163, 2003. https://doi.org/10.1016/S0742-7301(03)22003-X

24. K.L. Fonner, M.E. Roloff. Why Teleworkers are More Satisfied with their Jobs than are Office-Based Workers: When Less Contact is Beneficial. Journal of Applied Communication Research, vol. 38, pp. 336-361, 2010.

25. S. Hornung, J. Glaser. Home-Based Telecommuting and Quality of Life: Further Evidence on an Employee-Oriented Human Resource Practice. Psychological Reports, vol. 104, pp. 395-402, 2009.

26. R.S. Gajendran, D.A. Harrison. The Good, the Bad, and the Unknown About Telecommuting: Meta-Analysis of Psychological Mediators and Individual Consequences. The Journal of Applied Psychology, vol. 92, pp. 1524-1541, 2007. https://doi.org/10.1037/0021-9010.92.6.1524 